\title{
Elżbieta Dutka
}

Uniwersytet Śląski w Katowicach

\section{Melancholijne pejzaże Śląska}

Za sprawą wielu utworów literackich, fotografii i filmów utrwalony został industrialny pejzaż Śląska. Jego niezbędnym elementem są kopalniane szyby, buchające ogniem piece hutnicze, niezliczone rzędy kominów i zasnute dymami niebo. Wizerunek przemysłowego regionu utrwaliła $\mathrm{w}$ znacznej mierze literatura okresu dwudziestolecia międzywojennego, to wówczas Śląsk został na szerszą skalę wprowadzony do kultury polskiej. Świadectwem wzrastającego zainteresowania ziemiami przyłączonymi po powstaniach i po plebiscycie są liczne reportaże, które zostały po latach zebrane $\mathrm{w}$ antologii, opatrzonej znamiennym tytułem $-\mathrm{Z}$ czarnego kraju ${ }^{1}$. Redaktor tego zbioru - Wojciech Janota, zauważa, że w dwudziestoleciu międzywojennym wydawanie publikacji na temat Śląska nasilało się $w$ trzech okresach. Pierwszy nastąpił bezpośrednio po roku 1922, gdy zwracano uwagę na rozwój Górnośląskiego Okręgu Przemysłowego, przedstawiano różne aspekty asymilacji z resztą kraju. Druga fala zainteresowania Śląskiem przypada na czas kryzysu gospodarczego w latach 1930-1936. Trzecim okresem nasilonego zainteresowania regionem stał się rok 1938 - inkorporacja Śląska Zaolziańskiego ${ }^{2}$. Obszarem, który szczególnie zaistniał w tekstach publicystycznych i literackich, był „,czarny Śląsk” - przemysłowy obszar ówczesnych

1 Z czarnego kraju. Górny Śląsk w reportażu międzywojennym, teksty wybrał i wstępem opatrzył W. Janota, Katowice 1981.

2 W. Janota, Wstęp, w: tamże, s. 16. 
powiatów: katowickiego, świętochłowickiego, tarnogórskiego; miasta: Katowice, Chorzów, Mysłowice, Siemianowice:

Taki Śląsk jawił się jako wymarzony teren dziennikarskich penetracji, jako atrakcyjny i egzotyczny temat dla ludzi pióra z głębi kraju. Rozpoczęły się więc „najazdy" i zjazdy w podziemia kopalń, mnożyły się publikacje prasowe, relacje, impresje i reportaże. Śląsk był modny i funkcjonował nieustannie w świadomości ogólnopolskiej ${ }^{3}$.

Historię „nieznanego kraju” i jego specyfikę próbowała przybliżyć czytelnikom Zofia Kossak-Szczucka4 ${ }^{4}$ Pola Gojawiczyńska w głośnej Ziemi Elżbiety zwracała uwagę na codzienne życie w osadzie górniczej ${ }^{5}$. Pisarka pokazała losy Ślązaczek (matki i córki) na szerszym tle narastających w trudnych czasach kryzysu konfliktów społecznych oraz zmieniającej się mentalności i obyczajowości. Z tematyką górniczą swoje pisarstwo związał Gustaw Morcinek. Jednak to właśnie autor Wyrabanego chodnika zauważał, że obok „czarnego" można mówić także o Śląsku „zielonym” (obejmującym Podbeskidzie, Śląsk Cieszyński) i "białym” (nazywanym tak ze względu na wapienne skały - charakterystyczny element Wyżyny Śląskiej) ${ }^{6}$. Mimo wysiłków Morcinka, opisującego często zróżnicowany krajobraz regionu, wizerunek czarnego, przemysłowego Śląska zdominował literaturę nie tylko okresu dwudziestolecia międzywojennego, ale także kolejnych dekad. Do dziś pejzaż przemysłowy Śląska z szybami kopalnianymi i kominami, poziomami i skosami rur oraz linii przesyłowych, zdewastowaną powierzchnią ziemi, wysypiskami odpadów, hałdami, zapadliskami, familokami i chaotyczną zabudową miejską pozostaje swego rodzaju „wizytówką", znakiem rozpoznawczym tego miejsca. Mimo olbrzymiego zróżnicowania krajobrazowego regionu wciąż jest on $\mathrm{w}$ szerokim obiegu postrzegany w mocno skonwencjonalizowany sposób 7 .

3 Tamże, s. 8.

4 Z. Kossak-Szczucka, Nieznany kraj, Warszawa 1962. Pierwsze wydanie ukazało się w roku 1932. Zob. także: tejże, Na Śląsku, Lwów [bez roku wydania]; tejże, Skarb śląski, Poznań 1937.

5 P. Gojawiczyńska, Ziemia Elżbiety, Warszawa 1957. Pierwsze wydanie tej powieści ukazało się w 1934 roku.

$6 \mathrm{O}$,trójkolorowym” podziale Śląska pisze G. Morcinek w monografii etnograficznej Śląsk, wydanej w roku 1933 w serii „Cuda Polski”. Pisarz wspomina o tym także w książkach późniejszych - na przykład w opracowaniu zatytułowanym Górny Śląsk, Warszawa 1950, wydanym w ramach Biblioteki Polskiego Towarzystwa Krajoznawczego. O podziale Śląska na "czarny”, „biały” i „zielony” pisze również autor przedwojennego przewodnika - S. Berezowski, Turystyczno-krajoznawczy przewodnik po województwie śląskim, Katowice 1937 (reprint Katowice 1990).

7 Na temat zróżnicowania pejzażu śląskiego pisze A. Gomóła, Pejzaż śląski, czyli jaki?, w: Czło- 
Zainteresowanie Śląskiem ponownie nasiliło się na przełomie lat osiemdziesiątych i dziewięćdziesiątych XX wieku wraz $\mathrm{z}$ „emancypacją regionów”, wzrostem znaczenia lokalnych środowisk i rozwojem nurtu "małych ojczyzn". O dzieciństwie w Gliwicach pisał Adam Zagajewski w eseju Dwa miasta i Julian Kornhauser w "opowieści sentymentalnej" - Dom, sen i gry dziecięce ${ }^{8}$. Problematykę związaną z górniczym regionem podejmowali kolejni pisarze, między innymi: Feliks Netz w Urodzonym w Święto Zmartych i w Dysharmonii caelestis ${ }^{9}$, Henryk Waniek w Finis Silesiae i innych utworach ${ }^{10}$, Jacek Durski w poetyckiej powieści zatytułowanej Mariacka ${ }^{11}$. Mimo dużej konwencjonalizacji, stopniowego wyczerpywania się znaczenia wspomnianej tendencji w prozie, wciąż ukazują się kolejne utwory, podejmujące $\mathrm{w}$ ten sposób tematykę śląską - przykładem może być opublikowana w 2010 roku Piąta strona świata Kazimierza Kutza ${ }^{12}$. Spojrzeniu na Śląsk z szerszej perspektywy, odnajdywaniu uniwersalnego w lokalnym, sprzyjają eseje Stefana Szymutki zgromadzone w tomie Nagrobek ciotki Cili i szkice Aleksandra Nawareckiego zamieszczone w Lajermanie ${ }^{13}$. W wymienionych utworach, a także wielu innych tutaj nieprzypomnianych, odnaleźć można znany, tradycyjny obraz "czarnego kraju”, ale pojawiają się także nowe ujęcia, eksponujące przemianę Śląska w region postindustrialny - taką wizję (wybiegającą nawet w przyszłość) zarysowuje na przykład Grzegorz Kopaczewski w Hucie ${ }^{14}$.

Pragnę w tym miejscu zwrócić uwagę na przywołane powyżej dwie literackie odsłony pejzażu Śląska. Interesuje mnie przede wszystkim zapis doświadczenia przestrzeni industrialnej i postindustrialnej, widziany z punktu

wiek jest w drodze. Pejzaż ślaski - pamięć, tradycja, wspótczesność, red. A. Kowalczyk-Klus, R. Solik, Cieszyn 2008, s. 55-67. Skonwencjonalizowanym przedstawieniom pejzażu Śląska poświęca uwagę R. Solik, Pejzaż śląski - formy pamięci, w: Człowiek jest w drodze, s. 105. Zob. także K. Heska-Kwaśniewicz, Przestrzeń krajobrazowa Górnego Śląska w literaturze polskiej, czeskiej i niemieckiej, „Śląskie Miscellanea”, t. 11, red. J. Malicki, K. Heska-Kwaśniewicz, Katowice 1998, s. $147-161$.

8 A. Zagajewski, Dwa miasta, w: tegoż, Dwa miasta, Paryż-Kraków 1991; J. Kornhauser, Dom, sen i gry dziecięce. Opowieść sentymentalna, Kraków 1995.

9 F. Netz, Urodzony w Święto Zmartych, Katowice 1995; tegoż, Dysharmonia caelestis, Katowice-Warszawa 2004.

10 H. Waniek, Finis Silesiae, Wrocław 2003; tegoż, Katowice-blues czyli Kattowitzer-polka, Katowice 2010.

11 J. Durski, Mariacka, Katowice 1999.

12 K. Kutz, Piąta strona świata, Kraków 2010.

13 S. Szymutko, Nagrobek ciotki Cili, Katowice 2001; A. Nawarecki, Lajerman, Gdańsk 2010.

14 G. Kopaczewski, Huta, Wołowiec 2007. 
widzenia geopoetyki ${ }^{15}$. Szukając odpowiedzi na pytanie o związki pomiędzy konkretnym miejscem a jego literackimi reprezentacjami, proponuję porównanie dwóch bardzo różnych utworów, w których dostrzegam jednak zaskakujące podobieństwa. Zarówno w datowanych na rok 1936 Fotografiach ze Śląska Jarosława Iwaszkiewicza, jak i w krótkim szkicu Andrzeja Stasiuka I tak to się kiedyś wszystko skończy, napisanym zaledwie parę lat temu, odnajduję wyraźnie naznaczone melancholią spojrzenie na region i przekonanie o szczególnej „fotograficzności” tego miejsca ${ }^{16}$.

\section{„Symfonia surowej rzeczywistości”}

Fotografie ze Śląska Jarosława Iwaszkiewicza zostały po raz pierwszy opublikowane na łamach „Wiadomości Literackich”, w numerze w całości poświęconym krainie kopalń i hut ${ }^{17}$. Obok szkicu skamandryty we wspomnianym numerze pisma odnaleźć można cały szereg interesujących wypowiedzi na temat „nieznanego kraju” oraz fotografie i reprodukcje obrazów, ukazujących to miejsce. Po latach Iwaszkiewicz zamieścił swoją relację ze Śląska w tomie Podróże do Polski. W przedmowie do tej książki poeta wyjaśniał:

15 Pisząc o geopoetyce, przywołuję różnego rodzaju relacje pomiędzy literaturą a przestrzenią, budzące coraz większe zainteresowanie zarówno w refleksji teoretycznoliterackiej, jak i w praktykach twórczych. Termin "geopoetyka" spopularyzował Kenneth White - założyciel Międzynarodowego Instytutu Geopoetyki i redaktor "Cahiers de Géopoétique”. Według tego badacza i pisarza geopoetyka jest metodą badawczą, ale zarazem również pewną filozofią życiową, praktyką kulturową i programem literackim. Zob. m.in. K. White, Atlantica. Wiersze i rozmowy, wybrał, przeł. K. Brakoniecki, Olsztyn 1998; tegoż, Niebieska droga, przeł. R. Nowakowski, Warszawa 1992; tegoż, Poeta kosmograf, wybrał, oprac. i przeł. K. Brakoniecki, Olsztyn 2010. Definicję geopoetyki autorstwa tego badacza (geopoetyka to „studium związków intelektualnych i zmysłowych pomiędzy człowiekiem a Ziemią w celu wykształcenia harmonijnej przestrzeni kulturowej") przywołuje E. Rybicka w artykule Geopoetyka (o mieście, przestrzeni i miejscu we wspótczesnych teoriach i praktykach kulturowych), w: Kulturowa teoria literatury. Główne pojęcia i problemy, red. M.P. Markowski, R. Nycz, Kraków 2006, s. 479. Do propozycji White'a odnosi się również M. Czermińska, Miejsca autobiograficzne. Propozycja w ramach geopoetyki, „Teksty Drugie" 2011, nr 5, s. 184.

16 J. Iwaszkiewicz, Fotografie ze Śląska, w: tegoż, Podróże do Polski, Poznań [bez roku wydania], s. 146-159. Cytaty pochodzące z tego wydania oznaczam skrótem FzŚ, po którym podaję numer strony; A. Stasiuk, I tak to się wszystko kiedyśs skończy, w: W. Wilczyk, Czarno-biały Śląsk, teksty A. Stasiuk, W. Wilczyk, M. Grygiel, Katowice 2004, s. 5-6. Cytaty z tekstu A. Stasiuka oznaczam skrótem It, po którym podaję numer strony.

17 J. Iwaszkiewicz, Fotografie ze Śląska, „Wiadomości Literackie” 1936, nr 48, s. 11. 
Tytuł, który tym zebranym w jedno fragmentom nadałem, ma dwa znaczenia. Jedno przenośne, że niby to wszystko, co tu piszę i pisałem, jest jakąś podróżą do ojczyzny; drugi całkiem konkretny, bo najistotniejszą treścią tych kart są prawdziwe i rzeczywiste podróże do Polski. Tak się moja biografia złożyła, że trzykrotnie w ciągu mego życia "jechałem do Polski”, wybierałem się do mej ojczyzny jak gdyby z zewnątrz, zmierzałem ku niej - pół-pielgrzym, pół-turysta - zgadując tylko, co jest jej istotą, co jest jej powabem i mogąc ją porównywać $\mathrm{z}$ innym środowiskiem, $\mathrm{w}$ którym się pierwotnie zasiedziałem ${ }^{18}$.

Badacze widzą w Podróżach do Polski "rysowanie nowej, własnej mapy”, "stwarzanie ojczyzny" ${ }^{19}$, , docieranie do polskości" 20 , "gawędziarskie uzupełnienie przez Iwaszkiewicza swojej twórczości" ${ }^{21}$. Podobnie jak i inne podróże poety, również polskie peregrynacje mają przede wszystkim wymiar autobiograficzny ${ }^{22}$. W wydaniu książki, z którego korzystam, poszczególne podróże zostały zilustrowane fotografiami $\mathrm{z}$ archiwum Iwaszkiewicza, przedstawiającymi (między innymi) pisarza w domu w Stawisku, stojącego przed dworem w Byszewach, leżącego na łące w okolicach Sandomierza, oglądającego gliniany dzban na jarmarku w tym mieście czy spacerującego z córką ulicami Zakopanego. Paradoksalnie brakuje obrazów pisarza na tle przedstawianych miejsc we fragmencie Fotografie ze Ślaska, przywołującym zdjęcia już $\mathrm{w}$ tytule. Obok tekstu zamieszczono tu tylko dwie fotografie: pejzażu z dymiącymi kominami i Urzędu Wojewódzkiego w Katowicach. Podobnie pierwodruk szkicu na łamach „Wiadomości Literackich” został opatrzony fotografiami Józefa Bułhaka, przedstawiającymi krajobraz górnośląski. Brak zdjęć autora Fotografii ze Śląska upamiętniających pobyt w przemysłowym regionie wydaje się znaczący. Sądzę, że jest to najbardziej zaskakująca i intrygująca podróż $w$ całym tomie ${ }^{23}$. Inna wydaje się podczas tej wyprawy

\footnotetext{
18 J. Iwaszkiewicz, Od autora, w: tegoż, Podróże do Polski, s. 9-10.

19 W. Kot, Soczewki pamięci, w: Powroty Iwaszkiewicza, red. A. Czyżak, J. Galant, K. Kuczyńska-Koschany, Poznań 1999, s. 189-197.

20 H. Zaworska, Z Polski do Polski, „Twórczość” 1978, nr 7, s. 122-127.

21 A. Zawada, Jarosław Iwaszkiewicz, Warszawa 1994, s. 356-357.

22 „Wrażenia podróżne Jarosława Iwaszkiewicza [...] są właśnie taką próbą poszukiwania tożsamości poprzez przeszłość, poprzez zebranie rozproszonych elementów własnego życia i nadanie im znaczenia". D. Kozicka, Bo świat pełen szukania a nie masz mądrości. Autobiograficzne aspekty "Podróży do Włoch" Jarosława Iwaszkiewicza, w: tejże, Wędrowcy światów prawdziwych. Dwudziestowieczne relacje z podróży, Kraków 2003, s. 159. A. Zawada uważa, że Podróże do Polski są bardziej autobiografią niż Podróże do Włoch. Zob. A. Zawada, Jarosław Iwaszkiewicz, s. 355-356.

23 O odmienności Fotografii ze Śląska od innych fragmentów Podróży do Polski pisze G. Ritz: „Od obrazów tworzących dychotomię «wizja» i «autobiografia» istnieją dwa wyjątki: «Zakopane» i «Śląsk». Większość obrazów tatrzańskich pochodzi z wczesnych lat dwudziestych, natomiast ekspresjonistyczne widokówki śląskie Iwaszkiewicz pisze w 1936 r. Podczas gdy wzniosłość
} 
rola pisarza, raczej trudno w tym przypadku uznać go za „pół-pielgrzyma” czy „pół-turystę". Nie ma w szkicu porównań z innymi „środowiskami”, w których autor się "pierwotnie zasiedział”. Zamiast charakteryzującej podróżnika ciekawości, pragnienia poznania, dotarcia do istoty miejsca pojawia się dystans, a nawet przerażenie. Śląsk nie przypomina skamandrycie ani rodzinnej Ukrainy, ani okolic Stawiska czy ukochanej Sycylii - o podróżach poety do tych miejsc pisało wielu badaczy, podkreślając ich znaczenie dla twórczości autora Mapy pogody ${ }^{24}$. Krótkiego pobytu w Katowicach, Chorzowie i okolicach w latach trzydziestych XX wieku, którego efektem jest wspomniana relacja, nie odnotowują biografowie Jarosława Iwaszkiewicza ${ }^{25}$, brakuje zapisków na ten temat $\mathrm{w}$ dziennikach pisarza. Również w okresie późniejszym nie można raczej mówić o silnych więzach łączących autora Sławy $i$ chwały z przemysłowym regionem. Zaskakujący pogrzeb poety w mundurze górniczym trudno uznać za potwierdzenie przywiązania do "czarnego kraju". Prawnuczka Iwaszkiewicza - Ludwika Włodek, następująco przedstawia ten fakt:

Nad przebiegiem ceremonii czuwał Szymek [Szymon Piotrowski - sekretarz i kierowca Iwaszkiewicza, administrator Stawiska - przyp. E.D.]. To on decydował o wszystkim. Także o tym, jak Iwaszkiewicz będzie ubrany do trumny. Istotnie - mój pradziadek został pochowany w mundurze górniczym. Ale nieprawdą jest, że stało się tak na jego wyraźne życzenie. Nigdy nie zrobił też żadnego zapisu $\mathrm{w}$ testamencie na ten temat, a fragment ostatniego listu ze szpitala, o koszuli i butach do trumny, dobitnie pokazuje, że nie widział siebie wyruszającego $\mathrm{w}$ ostatnią drogę $\mathrm{w}$ tym stroju. Jak doszło do pochowania Iwaszkiewicza w mundurze górniczym, opowiedzieli mi, zupełnie niezależnie od siebie i zupełnie w innym czasie, mój ojciec i Andrzej Biernacki. Jednak ich historie brzmiały identycznie.

Pewnego dnia, zaraz po obiedzie, Jarosław gdzieś zniknął. Okazało się, że poszedł się przebrać. Po chwili skrzypnęły schody i zebrana w stołowym rodzina

naturalnego tła - przyrody, Tatr, nieba i gór - sprzyja przeżyciu metafizycznemu, egzystencjalnemu, które przesłania problem polskiej tożsamości, migawki ze Śląska sygnalizują groźbę zniszczeń związanych z uprzemysłowieniem, a także niesamowitą potęgę nowoczesnego postępu". G. Ritz, Jarosław Iwaszkiewicz. Pogranicza nowoczesności, przeł. A. Kopacki, Kraków 1999, s. 259.

24 Zob. np.: D. Kozicka, Bo świat pełen szukania a nie masz mądrości, s. 159-205; E. Sobol, Podróże Jarosława Iwaszkiewicza na Ukraine w okresie powojennym, w: Dziedzictwo Odyseusza. Podróż, obcość, tożsamość, red. M. Cieśla-Korytowska, O. Płaszczewska, Kraków 2007, s. 385-396; H. Zaworska, Sztuka podróżowania. Poetyckie mity podróży w twórczości Jarosława Iwaszkiewicza, Juliana Przybosia i Tadeusza Różewicza, Kraków 1980.

25 Zob.: M. Radziwon, Iwaszkiewicz. Pisarz po katastrofie, Warszawa 2010; G. Ritz, Jarosław Iwaszkiewicz. Pogranicza nowoczesności; R. Romaniuk, Inne życie. Biografia Jarostawa Iwaszkiewicza, t. 1, Warszawa 2012; A. Zawada, Jarosław Iwaszkiewicz. 
zobaczyła pradziadka w mundurze górniczym. Dostał go kilka dni wcześniej, gdy w Katowicach odbywał się uroczysty, uświetniony przez Gierka zjazd ZLP. Prezes Iwaszkiewicz został wtedy mianowany honorowym górnikiem kopalni „Staszic".

- O, taki prezent dostałem. Elegancki, czarny, w sam raz do trumny. Oszczędzi się na ubraniu - powiedział pradziadek i nikt z zebranych nie miał wątpliwości, że żartuje.

Nie wiem, czy Szymek nie poznał się na dowcipie, czy też złośliwie pochował swojego szefa $\mathrm{w}$ tym kompromitującym stroju. Nigdy też nie udało mi się dowiedzieć, dlaczego nikt $\mathrm{z}$ bliskich mojego pradziadka nie próbował tego uniemożliwić ${ }^{26}$.

Przywołuję tak obszerny fragment wyjaśnień Ludwiki Włodek, gdyż wokół pogrzebu poety narosło wiele legend, domysłów, które trudno obecnie zweryfikować. Podobnie jest z podróżami (realnymi i nie tylko) Iwaszkiewicza na Śląsk/ „do Śląska”. Nie tylko brakuje szczegółowych informacji na temat biograficznego kontekstu Fotografii ze Śląska, ale także interpretacji tego szkicu $^{27}$.

W Fotografiach ze Śląska uderza poczucie obcości, niezrozumienia odwiedzanego miejsca. To nie są wspomnienia pozwalające odnaleźć siebie w bliskiej przestrzeni, lecz raczej obrazy pejzażu, od którego podmiot czuje się oddalony, na który patrzy z dystansu przez obiektyw - „zimnym okiem kamery" [FzŚ, s. 150], wykonując zdjęcie, ale samemu nie sytuując się w fotografowanej przestrzeni. Taka pozycja wyjaśnia paradoksalną „nieobecnośćc podróżnego na fotografiach ukazujących opisywane miejsce. Dystans, oddalenie jest też kluczowym czynnikiem dla dokonywanej w tym tekście estetyzacji przestrzeni przemysłowej, pozwala dostrzec malowniczość okolicy ${ }^{28}$. Relacja poety jest złożona z szeregu odsłon, jakby stop-klatek ukazujących: most w Chorzowie, biedaszyby, cynkownię w Szopienicach, tunel kolejowy, fabrykę, ulicę, budynek Urzędu Wojewódzkiego w Katowicach i stary, drew-

\footnotetext{
26 L. Włodek, Pra. O rodzinie Iwaszkiewiczów, Kraków 2012, s. 337-338.

27 O śląskim fragmencie Podróży do Polski nie wspomina, analizując tę właśnie książkę, E. Łoch. Zob. E. Łoch, Jarosława Iwaszkiewicza "Podróże do Polski”, w: tejże, Pisarstwo Jarosława Iwaszkiewicza wobec tradycji i wspótczesności, Lublin 1988, s. 162-178.

28 Kwestia dystansu była kluczowa dla estetyzacji przestrzeni przemysłowych już w osiemnastym wieku - „Znaczenie odpowiedniej odległości pomiędzy podmiotem a przedmiotem wzrokowej kontemplacji dla uzyskania pełni doświadczenia estetycznego zgodnie podkreślali autorzy traktatów poświęconych zarówno wzniosłości, jak i malowniczości. Gdy Edmund Burke pisze, że rzeczy groźne czy przerażające mogą być źródłem przyjemności, zaznacza, że warunkiem koniecznym dla takiego odczucia jest oglądanie ich z "pewnej odległości»" M. Nitka, Pokłady wyobraźni: poetyka przestrzeni industrialnej, w: Przestrzeń w kulturze i literaturze, red. E. Borkowska, Katowice 2006, s. 47-48.
} 
niany kościół. Fotograf starannie kadruje rzeczywistość, zaznaczając, co jest $\mathrm{w}$ tle, a co na pierwszym planie.

Dodatkowo trudno oprzeć się wrażeniu, że pisarz patrzy na Śląsk w sposób zapośredniczony, gdyż jego literackie fotografie zaskakująco przypominają obrazy Rafała Malczewskiego, któremu ten szkic został dedykowany. Można ten gest odczytać jako wyraz solidarności pisarza z malarzem, który w tym czasie był mocno krytykowany za cykl obrazów Czarny Śląsk ${ }^{29}$. W numerze "Wiadomości Literackich", w którym po raz pierwszy został opublikowany szkic Iwaszkiewicza, zamieszczono także artykuł Plastyk na Ślqsku, w którym Malczewski odpowiadał na stawiane mu zarzuty, podkreślając swoją fascynację pejzażem przemysłowego regionu ${ }^{30}$. Również syn Jacka Malczewskiego w reportażach podkreślał, że spotkanie ze Śląskiem było dla niego przeżyciem wzruszającym, ale i wstrząsającym ${ }^{31}$. Plastyk eksponował charakterystyczną dla górnośląskiego pejzażu zabudowę przemysłową, krajobraz poprzecinany przez linie wysokiego napięcia, szyny, na tym tle ukazując prawie niewidoczne drobne figury ludzkie. Koloryt prac Malczewskiego jest ciemny, ożywiony czasem żółcią, czerwienią i innymi zaskakującymi intensywnością kolorami. Podobnie Fotografie ze Ślaska wydają się mroczne, utrwalające obraz "czarnego Śląska”, jednak dokładniejsze spojrzenie odsłania niespodziewanie cały szereg barw i odcieni. Kolorowa okazuje się już pierwsza literacka fotografia, zatytułowana Most $w$ Chorzowie. W kadrze znalazły się „rdzawe szkielety”, po których suną ruchome dźwigi, tworząc „zespół podobny do rytmu ich dwu barw, czarnej i rdzawej, każdy w dwóch odcieniach"; a także czerwony pociąg, strzelający białym dymem z czarnej lokomotywy, wozy pełne fiołkowej rudy, ogień buchający z pieców. Na dalszym planie są szarzy, czarni ludzie, niosący kosze purpurowych buraków, a tło wypełnia jesienne niskie niebo [FzŚ, s. 146]. Iwaszkiewicz, "fotografując" Śląsk, jest, podobnie jak Malczewski, przede wszystkim pejzażystą. Krajobraz Śląska ukazują właściwie wszystkie fragmenty tego szkicu, a aż cztery spośród nich informują o tym bezpośrednio poprzez swoje tytuły: Pej-

${ }^{29}$ Cykl obrazów Czarny Ślask został pokazany w latach 1935-1936 na wystawach w Warszawie, Katowicach i Łodzi. Na ten temat pisze: S. Potępa, Rafał Malczewski, Tarnów 2006, s. 109-121. Autor monografii malarza zauważa, że cykl nie został przychylnie przyjęty. Artyście zarzucano brak ",autentyczności przeżycia i, co najważniejsze, tchnienia bytu ludzkiego" [tamże, s. 111], pisano, że „właściwa temu malarzowi maniera chimeryzowania rzeczywistości zmienia jego Śląsk w mroczną i fantastyczną krainę pozbawioną cech lokalnych” [tamże, s. 112], choć były także głosy inne - „Rafał Malczewski odczuł grozę pejzażu śląskiego, obsianego kominami i piecami, ale w ramach pejzażu nie dojrzał człowieka" [tamże, s. 114].

30 R. Malczewski, Plastyk na Śląsku, „Wiadomości Literackie” 1936, nr 48, s. 20.

31 Zob. R. Malczewski, Pierwszy niuch, w: Z czarnego kraju, s. 84-87; R. Malczewski, Fedruje śląski krajobraz, w: Z czarnego kraju, 106-110. 
zaż z tunelem, Pejzaż z kościołem, Pejzaż z mostami, Pejzaż z karuzelą. Malarz na swoich obrazach pokazuje pustkę, awangardowość i swego rodzaju "chorobliwość" pejzażu śląskiego. Olbrzymie budynki przemysłowe, kominy i piece dominują w pejzażu regionu, są znakiem nowoczesności. W reportażach Malczewski pisze o walce z żywiołem „czarnych tętnic ziemi, z płomienną grozą metali rozgniatanych, rozdzieranych, kowanych przez niewolnika i pana ludzi: maszynę". W spojrzeniu plastyka ogromną rolę odgrywają porównania anatomiczne, sugerujące niezwykłą „cielesność" przemysłowego regionu. Spotkanie ze Śląskiem oznacza tu silne doznanie fizyczności, materialności. Zderzają się w spojrzeniu plastyka dwie tendencje: do uczłowieczenia pejzażu i do odczłowieczenia mieszkańców. Człowiek jest przez Malczewskiego postrzegany łącznie z maszyną, staje się swego rodzaju automatem i jednym ludzko-mechanicznym organizmem. Malarz pisze o „naskórku gleby”, zrytym i poszarpanym, z guzami hałd i szlaki, o osiedlach i miastach zlewających się w jeden organizm, domach zbudowanych z ",anemicznej" cegły, pokrytej nalotem sadzy, pagórach żużli koloru wątroby:

W środku zaś tych nabrzmiałych pagórów [podkreśl. - E.D.] tkwią obozy walki - kopalnie, huty, fabryki zamknięte murami jak średniowieczne twierdze. Poza nimi dzieją się jakieś rzeczy wielkie, dostępne dla wtajemniczonych i zaufanych. Pogodne niebo nad tym krajobrazem wydaje się raczej zbyteczne i dopiero wywatowane chmurami zlewa się doskonale ze sprawami sponiewieranej ziemi. Wtedy wszystko wtopione w mokrą szarość, pozbawione jakichkolwiek słodkich uroków, odarte z romantycznych wdzięków uderza patrzącego posępną wielkością: te wypaproszone ziemie, czarne domy, złomy i iglice kopalń, hut, twardzi ludzie i niełaskawe niebo ${ }^{32}$.

Przywołany opis jest tak szczegółowy, akcentujący materialność przemysłowego regionu, dosadnie eksponujący kolorystykę, że wręcz można odnieść wrażenie namacalności przedstawionej przestrzeni. Efektem tego jest odczucie osaczenia i zagubienia, które jednak nie wyklucza fascynacji, „smakowania” odmienności stron naznaczonych przemysłem - „mieszaniny pejzażu”, "spitraszonej" z "grozy i potęgi, ze szczerego smętku, serdecznej melancholii i cierpkiego humoru" ${ }^{33}$. Skamandryta podobnie jak Malczewski eksponuje cielesność, ale i zarazem martwotę krajobrazu, naszpikowanego kominami, drutami, liniami kolejowymi, a także martwotę ",czarnych, szarych, nędznych ludzi” [FzŚ, s. 146], automatycznie wykonujących codzienne czynności. Materialność pejzażu śląskiego, skojarzona $\mathrm{z}$ chorobą, śmiercią, potęguje myśli o skończoności świata i ludzkiego życia.

\footnotetext{
32 R. Malczewski, Pierwszy niuch, s. 86.

33 R. Malczewski, Fedruję krajobraz ślaski, s. 107-108.
} 
Postacie zredukowane na obrazach malarza i na literackich fotografiach do małych punktów nie są jednak wcale nieważne, nieistotne. Wprost przeciwnie, to właśnie ta dysproporcja pomiędzy człowiekiem i innymi elementami industrialnego pejzażu wydaje się istotą przedstawień malarza i pisarza. Malczewski na zarzuty, że nie przedstawił mieszkańców przemysłowego regionu, odpowiedział: „Zanim wprowadzę ludzi do mych kompozycji ze Śląska, muszę poznać głęboką logikę i sens ich trudu" ${ }^{34}$. Iwaszkiewicz natomiast o zaskakującej dużej roli przedstawienia postaci (mimo ich pozornej nieważności) pisze, opatrując pejzaż ukazujący hałdy i biedaszyby znamiennym komentarzem:

Małe czarne wzgórki rosną i na przemian z małymi dołkami ozdabiają cały skłon górki. Widzę na tym cmentarzu jedną tylko babę. Starucha, pochylona głęboko, wykopuje z dołka jakieś białawe i czarne kawałki. To biedaszyby.

Niebieska spódnica starej, o ton ciemniejsza od nieba, jaśniejsza od dymu, jest tylko nikłą plamą $w$ tej symfonii surowej rzeczywistości [podkreśl. - E.D.]. Nie ma żadnego znaczenia. A jednak bez niej obraz nie istniałby. Jak czasem na płótnie dobrego malarza jedna nikła a drobna plama kończy całą kompozycję i stanowi treść obrazu, tak ta baba pochylona nad mogiłką, wydobywająca stamtąd czarne grudki, rozwiązuje znaczenie pejzażu [FzŚ, s. 148].

Drobne postacie: kobiety na hałdzie, leżącego żebraka czy małego „czarniawego" chłopczyka ciągnącego wózek, stają się punctum literackich fotografii - „użądleniem, raną, przecięciem" 35 . Takie ujęcia mówią nie tylko o „znaczeniu pejzażu" i o mechanizmach związanych z uprzemysłowieniem, z podporządkowaniem człowieka maszynie, którą sam wcześniej stworzył. Sądzę, że mówią także o samym fotografie wykonującym te zdjęcia, o jego bezradności wobec wymykającej mu się rzeczywistości, której nie potrafi zracjonalizować, wyjaśnić, usensownić. W uprzedmiotowieniu mieszkańców, postrzeganych nie w sposób zindywidualizowany, ale jako swego rodzaju część pejzażu, maszyny lub czarny, szary tłum, „zbiegowisko” [FzŚ, s. 155], „lud” [FzŚ, s. 158], wyraża się rezygnacja, swego rodzaju sceptycyzm poznawczy.

\footnotetext{
34 Tę wypowiedź, zamieszczoną w „Pionie” 1935, nr 24, s. 5, przywołuje Z. Krzykowska, podkreślając, że na obrazach Malczewskiego człowiek jest „istotą bezradną wobec potężnego i imponującego, ale niszczącego jego otoczenie przemysłu", a ekspresja tych przedstawień wynika „Z obiektywnej prawdy, spotęgowanej przez syntetyczną kompozycję, tworzącą nastrój pustki szarzyzny surowego, niemal księżycowego pejzażu". Z. Krzykowska, Słowo wstępne, w: Twórczość Jacka i Rafała Malczewskich. Katalog wystawy. Muzeum Śląskie w Katowicach, komisarz wystawy, scenariusz, oprac. katalogu Z. Krzykowska, Katowice [bez roku wydania], s. 7. 35 „Punctum jakiegoś zdjęcia to przypadek, który w tym zdjęciu celuje we mnie (ale też uderza mnie, uciska)" - R. Barthes, Światło obrazu. Uwagi o fotografii, przeł. J. Trznadel, Warszawa 1996, s. 47 .
} 
Język wydaje się niewiarygodny, dlatego komentarze, refleksje są w tym szkicu ograniczone, zamiast gawędy są obrazy. To spojrzenie melancholika, wiążące dwa aspekty doświadczenia: estetyczny i egzystencjalny ${ }^{36}$. Fascynacja odmiennym widokiem, pejzażem niezwykle plastycznym spotyka się tu z poczuciem niezrozumienia, obcości. Uderza przesadna estetyzacja pejzażu śląskiego, przyrównanie kominów do harfy siedmiostrunnej, pieców hutniczych do tabernakulum świątyni, fabryki do opery paryskiej. Z jednej strony jest tu „symfonia surowej rzeczywistości” [FzŚ, s. 148], a z drugiej - poczucie pustki, sztuczności, martwoty, braku języka. Dopiero w ostatnim fragmencie dostrzec można przekroczenie granicy dzielącej podmiot od opisywanego miejsca, zbliżenie. Poeta przyjechał zbyt późno, nie można już zrobić zdjęcia, trudno rozróżnić kształty ze względu na mrok i deszcz jesienny. Podróżny zatem jedynie dotyka ściany drewnianego kościoła, odczuwając w ten sposób po raz pierwszy, wręcz cieleśnie bliskość tego miejsca:

Gdy naciskam dłoń, czuję dreszcz przebiegający pod drewnianą skórą [...]. Ileż martwych, niemych okropnych przedmiotów widziałem $\mathrm{w}$ ciągu dzisiejszego dnia. Jak bardzo gdzieś zabłądziła ludzkość, pracując nad stwarzaniem tak strasznej martwoty. Gdzieś - nie wiem gdzie - popełniła błąd i odtąd zawsze do tego błędu powraca. A oto ta drewniana świątynia pulsuje pod moją ręką niekłamanym życiem rzeczy wiecznych [FzŚ, s. 158].

W tym somatycznym doznaniu następuje swego rodzaju przekroczenie, porzucenie dotychczasowego „bezpiecznego” dystansu. Na krótki moment kontemplacja krajobrazu i jego estetyzacja zostają zastąpione przez bezpośrednie, bo wręcz somatyczne doznanie.

\section{„Miejsce zużyte”}

Związki pisarstwa Andrzeja Stasiuka ze Śląskiem, podobnie jak w przypadku twórczości Jarosława Iwaszkiewicza, mają raczej charakter epizo-

\footnotetext{
36 „Ten ścisły związek [aspektu estetycznego i egzystencjalnego doświadczenia - przyp. E.D.] pokazuje nie tylko niemożność pełnej konstytucji, ustanowienia dojrzałej podmiotowości, dla której istnienie w porządku symbolicznym [...] nie byłoby rodzajem udręki i źródłem niedającego się zrekompensować cierpienia. Wydaje się bowiem, że to właśnie ten moment kryzysu, w którym zostają skonfrontowane sprzeczne porządki doświadczenia wewnętrznego oraz powszechnego języka, zewnętrznego wobec podmiotu systemu znaczeń oraz konieczność ochrony autonomii własnego ja, staje się najistotniejszym elementem $\mathrm{w}$ strukturze podmiotu melancholicznego". J. Momro, Akt etyczny i histeria - dwie twarze melancholii. O eseistyce Marka Bieńczyka, w: Nowe dwudziestolecie. Szkice o wartościach i poetykach prozy i poezji lat 1989-2009, red. P. Śliwiński, Poznań 2011, s. 105.
} 
dyczny. "Czarny kraj" nie jest ulubionym tematem i kierunkiem wypraw realnych i literackich autora Jadąc do Babadag. Dla skamandryty swego rodzaju przewodnikiem po nieznanym mu regionie były obrazy Rafała Malczewskiego, w przypadku szkicu I tak to się wszystko kiedyśs skończy taką rolę spełniają fotografie Wojciecha Wilczyka.

Tekst Andrzeja Stasiuka został zamieszczony w albumie fotografii, zatytułowanym Czarno-biały Ślask. W publikacji zgromadzono zdjęcia wykonane przez Wojciecha Wilczyka w latach 1999-2003. Parę lat wcześniej (w latach 1992-1996) fotografik realizował w Rudzie Śląskiej projekt Pejzaż symboliczny, w ramach którego dokumentował rozbiórkę koksowni "Walenty" 37 . Artystę zafascynowały ruiny, które pozostały po tym zakładzie zbudowanym na początku XX wieku. Na czarno-białych fotografiach betonowe wieże, silosy, pozostałe fragmenty koksowni stały się "tajemniczymi budowlami o symbolicznym znaczeniu, [...] czasami są przerażające w swojej wymowie, a czasami piękne niczym fantastyczna architektura" ${ }^{38}$. W swoim kolejnym projekcie fotografik utrwalał zmiany pejzażu postindustrialnego regionu, przedstawiając zaniedbane osiedla mieszkaniowe, niszczejące fabryki, opuszczone, zapomniane miejsca na Górnym Śląsku. Zdjęcia zgromadzone w albumie Czarno-biały Śląsk przedstawiają stare, zaniedbane domy w Bytomiu, Zabrzu i innych miastach, pejzaże ze zrujnowanymi fabrykami, odbijającymi się w wodzie wypełniającej zapadliska. Dominującym tematem fotografii jest rozkład, rozpad - zagadnienia, w których "specjalizuje się" również Andrzej Stasiuk ${ }^{39}$. Przedstawiona na fotografiach przestrzeń wydaje się opuszczona, pusta, wręcz nierealna, jak zauważa Ewa Gorządek (z Centrum Sztuki Współczesnej Zamek Ujazdowski w Warszawie):

Ludzie na fotografiach z cyklu Wilczyka występują najczęściej w roli anonimowych świadków lub statystów. Kadry są skrupulatnie przemyślane, syntetyczne $\mathrm{w}$ formie ujętej $\mathrm{w}$ geometryczne podziały horyzontalne $\mathrm{z}$ wyraźną dominantą pierwszego planu. Widoki miejskich pejzaży współistnieją tu $\mathrm{z}$ wizerunkami kompleksów przemysłowych, fragmentów koksowni, zamkniętych fabryk i hut, porośniętych zielskiem ślepych torowisk, tworząc panoramę swoistego „krajobrazu po bitwie" 40 .

37 Cykl zdjęć Pejzaż symboliczny został zaprezentowany na wystawie w Galerii ZPAF w Krakowie w 1997 roku. O początkach swojej fascynacji pejzażem postindustrialnego Śląska i swoim sposobie fotografowania Wojciech Wilczyk pisze w tekście Czarno-biały Śląsk, w: tegoż, Czarno-biały Śląsk, s. 7-12.

38 E. Gorządek, Wojciech Wilczyk, http://www.culture.pl/baza-sztuki-pelna-tresc [dostęp 30.11.2012 r.].

39 Zob. np. R. Ostaszewski, Specjalność: rozpad, „Tygodnik Powszechny” 2004, nr 29, s. 19.

40 E. Gorządek, Wojciech Wilczyk. 
Pisząc komentarz do zdjęć swojego rówieśnika ${ }^{41}$, Stasiuk w charakterystycznym dla siebie "fotograficznym" stylu przedstawia cały szereg obrazów-kadrów, zbudowanych zaledwie z kilku wyrazistych zdań ${ }^{42}$. Enumeracyjny tok daje wrażenie monotonii, przypomina powrót natrętnych, obsesyjnych myśli, od których nie sposób się uwolnić. Tak częste w utworach Stasiuka gromadzenie obrazów z kolekcjonerską pasją przywodzi na myśl słowa Susan Sontag:

Ucząc nas nowego kodu wzrokowego, fotografie zmieniają i rozszerzają pojmowanie tego, co zasługuje na oglądanie, i tego, co mamy prawo zauważyć. Stanowią gramatykę i - co jeszcze ważniejsze - etykę widzenia. Wreszcie, najbardziej pompatycznym wynikiem fotograficznego przedsięwzięcia jest poczucie, iż jesteśmy w stanie cały świat zmieścić w głowie jako antologie obrazków. Zbierać fotografie - to zbierać świat ${ }^{43}$.

Badaczka dzieli fotografów na naukowców, którzy sporządzają inwentaryzację świata, i moralistów, skupiających uwagę na trudnych przypadkach ${ }^{44}$. Stasiuk jako literacki fotograf dokonuje przede wszystkim inwentarza świata (odpowiadają temu takie środki jak wyliczenia, powtórzenia), nie ucieka jednak od selekcji i oceny. Rozpadające się budynki fabryczne, opuszczone miejsca, w których kiedyś tętnił przemysł, wydają się bardziej „fotograficzne" niż rzeczy powszechnie uważane za ważne i piękne. Można w tym widzieć „surrealistyczny gust”, tak bliski fotografii, oznaczający "chroniczne upodobanie do śmieci, odrażających widoków, wyrzutków, łuszczących się powierzchni, dziwactw, kiczu" ${ }^{\prime 4}$. Świat oglądany fotograficznie potwierdza uczucie, że wszystko niszczeje, rozpada się, przemija, a rzeczywistość jest w gruncie

41 W. Wilczyk jest o rok młodszy od A. Stasiuka, urodził się w 1961 roku w Krakowie. Artysta zajmuje się fotografią, ale jest także autorem esejów, wierszy i tekstów o sztuce. Zrealizował kilka interesujących dokumentalnych projektów fotograficznych, obok wspominanego Czarno-białego Śląska (w latach 1999-2003): Kalwaria (1995-2004), Życie po życiu (2004-2006), Postindustrial (2003-2007), Niewinne oko nie istnieje (2006-2008) - ten projekt był nominowany do Deutsche Börse Photography Prize.

42 Na temat „fotograficzności” prozy A. Stasiuka piszą m.in.: E. Dutka, "Przestrzeń wspóttworzenia" - o fotografii w pisarstwie Andrzeja Stasiuka, „Media. Kultura. Komunikacja Społeczna” 2009, nr 5, s. 268-287; K. Dzika-Jurek, Głos w sprawie kilku zdjęć. Pewne "fotografie" Stasiuka i Dehnela, "Świat i Słowo" 2009, nr 2, s. 197-205; M. Koszowy, Jadąc do Abony. Fotograficzne podróże Andrzeja Stasiuka, „Teksty Drugie” 2007, nr 1/2, s. 249-260; R. Ostaszewski, Specjalność: rozpad.

43 S. Sontag, O fotografii, przeł. S. Magala, Warszawa 1986, s. 7. „Fotografie, działając wedle zasad surrealistycznej wrażliwości, sugerują, że daremne jest nawet silenie się na zrozumienie świata, i zamiast tego proponują, byśmy świat kolekcjonowali" - tamże, s. 81.

44 Tamże, s. 59.

45 Tamże, s. 77. 
rzeczy nieklasyfikowalna, ujmowana w przypadkowe ujęcia. Dla Susan Sontag fotografie są zatem "melancholijnymi przedmiotami”, podobnie traktuje je melancholik $\mathrm{z}$ utworów Stasiuka ${ }^{46}$. Pisarz dostrzega na fotografiach z cyklu Czarno-biały Ślask coś więcej niż tylko reportaż z postindustrialnego regionu. Pejzaż śląski utrwalony na zdjęciach Wilczyka staje się pretekstem do refleksji o charakterze bardziej ogólnym. Zamierające kopalnie, zarastające huty są laboratorium przemijania, jednym wielkim eksperymentem i pytaniem o przyszłość:

Takie są wróżby. Takie myśli przychodzą do głowy. Co będziemy robić z naszych miast? Na co przerabiać nasze fabryki? Będziemy z nich wykonywać nasze autostrady, żeby odjeżdżać coraz dalej od niepotrzebnych zużytych miejsc [podkreśl. - E.D.], od dziur w ziemi wypełnionych trującą wodą i znajdować nowe miejsca na nowe miasta, ponieważ będzie się na nie zwiększał popyt? [It, s. 5]

Porzucone, zaniedbane budynki przemysłowe stają się niepotrzebnym elementem pejzażu, czymś zbędnym, czego należy się pozbyć. Owa „niepotrzebność" jest szczególnie uderzająca wówczas, gdy okazuje się, że zbędne są całe obszary, kwartały ulic, części miast. Stasiuk, podążając tropem wyznaczonym przez fotografika, zwraca uwagę na "miejsca zużyte”:

To są huty, kopalnie, koksownie, elektrownie. Zgasły, wyczerpały się, wypaliły, zniszczały, wygasły. To są domy, w których już się namieszkało, w których się powymierało. Przyjadą wielkie auta, żeby to gdzieś wywieść i wyrzucić. To dziwnie brzmi, ale trzeba wywozić i wyrzucać domy i miasta, żeby zrobić miejsce dla następnych, które też się kiedyś wywiezie i wyrzuci [It, s. 5].

Podobnie jak w reportażach Rafała Malczewskiego, także w szkicu autora Fado pojawiają się anatomiczne porównania. Stasiuk dostrzega "cielesność" poindustrialnego pejzażu, jego zarażenie przemijaniem, śmiercią:

To wszystko wygląda jak szkielet, od którego odpada mięso, i dopiero teraz widać, jak było zrobione. Można tu przychodzić jak na cmentarz, żeby się pogodzić i przygotować. Dopiero teraz, gdy się rozlatuje, widać, że było tego za dużo, że było niepotrzebne i nic się właściwie nie stało, gdy już tego nie ma [It, s. 6].

Współczesność, która odpycha myśl o śmierci, o rozkładzie, usuwa również ruiny. Nie ma na nie miejsca w świecie wiecznej młodości. Pisarza niepokoi ten proces wywożenia resztek, likwidowania pozostałości. Unaoczniają

46 Zob. W. Rusinek, O podmiotowości melancholijnej w prozie Andrzeja Stasiuka, w: Z dziejów podmiotu i podmiotowości w literaturach słowiańskich XX wieku, red. B. Czapik-Lityńska, M. Buczek, Katowice 2005, s. 58-69. 
go przemiany industrialnego pejzażu (na przykład rozkopywane, zrównywane z ziemią hałdy, z których pozyskiwany jest materiał od budowy dróg, bądź też rozbierane lub pośpiesznie przerabiane na inne cele budynki dawnych fabryk):

Żeby zbudować miasto albo fabrykę, trzeba było wydobyć z ziemi dużo rzeczy. Nie dało się budować $\mathrm{z}$ powietrza ani $\mathrm{z}$ wody. Teraz trzeba to $\mathrm{z}$ powrotem gdzieś zagrzebać, a wcześniej gdzieś wywieźć, te wszystkie kamienie, żelastwo, te minerały, cegły, beton i resztę. Nie można tego zostawić tak, jak robiło się kiedyś. To może znaczyć, że nie będzie już czegoś takiego jak ruiny. Nic nie doczeka do naturalnego końca, nic nie rozpadnie się ze szczętem i zamiast tego nastąpi jakaś wiekuista rozbiórka i wywózka [It, s. 5].

Przemysłowy region w sposób zaskakujący, szczególny nie pozwala jednak zapomnieć o śmierci, paradoksalnie betonowe ruiny przywołują starzejące się, obumierające ciało. W szkicu Stasiuka powraca motyw obecny już w reportażach Rafała Malczewskiego i w szkicu Jarosława Iwaszkiewicza - uczłowieczenie przestrzeni regionu. Pejzaż śląski tworzy zdarty naskórek ziemi, rozdarte warstwy obnażają wnętrzności - trzewia ziemi. Wspólnota $\mathrm{z}$ „ludzką" okolicą ma charakter melancholijny i - jak zauważa Marek Bieńczyk w swoim studium o melancholii - związek z ziemią przybiera wiele odcieni: od współczucia dla materii, „przez ciężką rezygnację i zgodę na nią, aż po doznanie uwięzienia w materii (własnego ciała i ciała ziemi), czy wręcz po obsesję niewytłumaczalnej, niepojętej organiczności rzeczy" ${ }^{47}$. Doznanie materialności ziemi, sensualne odczucia z tym związane (widoku, zapachu, smaku), tak charakterystyczne dla rozkopanych, zrytych przestrzeni Śląska, tworzą doświadczenie melancholijne ${ }^{48}$.

Andrzej Stasiuk nie pozostaje w kręgu melancholijnej eschatologii, lecz stawia także pytania o przyszłość. Ryszard Solik pisze, że pejzaż śląski, jak mało który, z sugestywną siłą "skłania do fundamentalnych zapytań o to, kim jesteśmy, skąd przychodzimy i dokąd zmierzamy" ${ }^{49}$. Takie pytania zadaje pisarz, obserwując nowe życie - które go fascynuje, ale i przeraża odradzające się na postindustrialnych ruinach:

Nie do wiary, ale widać jak w szczeliny wpełza trawa, a z zatrutych miejsc wyrastają drzewa. Pojawia się woda w kałużach, w wodzie odbijają się obłoki. Wszystko wskazuje na to, że na końcu będzie jednak tak samo, jak było na początku. Pejzaż po prostu się zasklepi za pomocą nieba, wody i roślin, zrośnie

\footnotetext{
47 M. Bieńczyk, Melancholia. O tych, co nigdy nie odnajda straty, Warszawa 1998, s. 49.

48 Tamże, s. 50.

49 R. Solik, Pejzaż śląski - formy pamięci, s. 108.
} 
się, i cały ten industrialny epizod pójdzie w zapomnienie. Drzewa będą się karmić niejadalnymi resztkami.

No tak, ale wtedy już nikt nie będzie robił zdjęć [It, s. 6].

„Postindustrial” w szkicu Stasiuka okazuje się nową formą istnienia. Jest to swego rodzaju "życie po życiu” miejsca. Znamienne jest to, że właśnie tak zatytułowane są dwa kolejne projekty Wojciecha Wilczyka. Zdjęcia z cyklu Życie po życiu przedstawiają wycofane z eksploatacji samochody, używane w odmiennej funkcji - na przykład jako kwietniki, przydomowe dekoracje lub przydrożne reklamy ${ }^{50}$. Natomiast w ramach projektu Postindustrial artysta dokumentuje nieczynne obiekty przemysłowe w Polsce i w Niemczech ${ }^{51}$. W tych nowych formach nie ma już jednak miejsca na melancholię, o której przypominałyby "melancholijne przedmioty” - zdjęcia. Nowe formy są wyzute z historii, pozbawione "ciężaru”.

Pejzaż postindustrialnego Śląska nasuwa myśl o życiu, które staje się coraz dłuższe, ale przez to dłuższa staje się przede wszystkim starość, a człowiek doświadcza coraz więcej cierpienia, przemijania. Na obrazach i w reportażach Rafała Malczewskiego, a także w Fotografiach ze Śląska Jarosława Iwaszkiewicza spojrzenie na pejzaż śląski uświadamiało dominującą rolę przemysłu, któremu człowiek został podporządkowany, stając się wręcz jego zakładnikiem. Zdjęcia Wojciecha Wilczyka i szkic Andrzeja Stasiuka stają się antropologicznym rozpoznaniem świadomości człowieka współczesnego - korzystającego z dobrodziejstw późnej nowoczesności, ale także ponoszącego konsekwencje tego czasu. Coraz dłuższe życie, które jest osiągnięciem cywilizacyjnym, spełnieniem odwiecznych marzeń, zderzone zostało z szybkością życia, która przyspiesza przemijanie, zużycie. Ze względu na tempo życia, szybkość egzystencji, niespotykaną wcześniej, zmagania z przemijaniem i śmiercią nabierają w szkicu Stasiuka cech pyrrusowego zwycięstwa:

Starość zrobiła się szybka, a życie krótkie. Tyle teraz jest tego i tamtego, i wszystko chce się załapać, chce mieć swoje pięć minut. Rano coś jest nowe, a wieczorem już do niczego. To oczywiście smutne, ale inaczej już pewnie nie będzie. Człowiek żyje coraz dłużej tylko po to, żeby oglądać coraz więcej rozpadu w coraz dłuższym życiu, w coraz dłuższej starości [It, s. 5].

Myśl, do której skłania obserwacja pejzażu Śląska, wiąże się z kolejnym zagadnieniem powracającym wręcz obsesyjnie w wielu utworach Andrzeja

50 Wystawa fotografii W. Wilczyka z cyklu Życie po życiu zorganizowana w 2007 roku w Centrum Sztuki Współczesnej Zamek Ujazdowski w Warszawie.

51 Cykl zdjęć zatytułowany Postindustrial pokazano w 2004 roku w Galerii Zderzak w Krakowie. 
Stasiuka - w rozmowie na temat Grochowa jako książki o umieraniu pisarz stwierdził:

chcemy żyć dłużej, czyli tak naprawdę przedłużamy agonię, cały czas się łudzimy nadzieją nieśmiertelności, prowadzimy ze śmiercią tę cholerną grę: jeszcze dzień, jeszcze miesiąc, jeszcze trochę, a może coś wynajdą. [...] Teraz mami nas złudzenie fizycznej nieśmiertelności ${ }^{52}$.

Autor Jadąc do Babadag poprzez fotografie Wilczyka patrzy na Śląsk podobnie jak na "swoją" "gorszą" Europę. Stasiuk widzi w tym regionie miejsce, które przemija, jest obdarzone niezwykłym klimatem (jaki nadaje świadomość umierania, odchodzenia), miejsce, które współtworzy „melancholijną geografię kontynentu". W eseju Fado pisarz zauważa:

mógłbym znaleźć w pamięci dziesiątki innych miast. Ba, mógłbym znaleźć całe krainy i całe państwa, które we władanie wzięła melancholia. Jeśli tylko wystarczy mi czasu i sił, napiszę kiedyś melancholijną geografię naszego kontynentu. Znajdą się w niej miejsca, których nikt nie odwiedza, miejsca, których teraźniejszością jest przeszłość, miejsca, które zostały wydane na łup czasu, tak jak kiedyś wydawane były na łup barbarzyńców ${ }^{53}$.

Znamienne, że w antologii Znikająca Europa, z której pochodzi przywołany wyżej esej Andrzeja Stasiuka o fascynacji terenami poprzemysłowymi, zamieszczono zdjęcia pochodzącego z Bytomia fotografa - Tomka Mżyka, z cyklu Silent Industry, ukazujące Górny Śląsk ${ }^{54}$. "Czarny kraj” został tym samym wpisany na mapę tytułowej „znikającej Europy”. Zarówno na zdjęciach, jak i w eseju niemal nierealny postindustrialny krajobraz ma w sobie coś infernalnego, ale zarazem spokojnego, jest pełen rezygnacji, wywołuje melancholię. Ta przestrzeń pisarzowi kojarzy się z portugalskim fado, pieśnią losu, która pozwala jeszcze bardziej dostrzec melancholię miejsca:

Ostatnie i zagubione - to zaprząta moją wyobraźnię. To, co nowe i obiecujące, nigdy mnie nie pociągało. Początek ani rozwój nie są ekscytujące. Dopiero, gdy miejsce się zestarzeje, gdy jego czas się dopełnia, można w tym znaleźć coś ludzkiego. Tylko w tym, co minione, możemy przeglądać się jak w lustrze.

\footnotetext{
52 Duch i oko materii, z A. Stasiukiem rozmawia R. Koziołek, „Tygodnik Powszechny” (dodatek „Conrad") 2012, nr 46, s. 44.

53 A. Stasiuk, Fado, w: Znikająca Europa, red. K. Raabe, M. Sznajderman, Wołowiec 2006, s. $371-372$.

54 T. Mżyk, fotografie z cyklu Silent Industry, Górny Śląsk, w: Znikająca Europa, s. 264, 282, $315,316$.
} 
Tylko to, co niedoskonałe, niesie nam pociechę, ponieważ wtedy odkrywamy, że nie będziemy umierali samotnie ${ }^{55}$.

Melancholia miejsca łączy Fotografie ze Śląska Jarosława Iwaszkiewicza z I tak to się kiedyś skończy Andrzeja Stasiuka. Wspólny jest także motyw fotografii - "melancholijnego przedmiotu”, oraz pozorna nieobecność człowieka, gdy w istocie przedstawiany pejzaż mówi właśnie o człowieku. Parafrazując słowa Marka Bieńczyka, można powiedzieć - „melancholijny region jest kliszą", wstępujemy w niego za sprawą utworów Iwaszkiewicza i Stasiuka jak w zdjęcie, ma on w sobie "coś hiperrealistycznego, nadwyrazistość szczegółu [...] utrwalonego raz na zawsze", "tu na lewo ubytek i pleśń, tam na prawo przejmującą pustkę"; toczy się tu jakiś film, ale my nie dostrzegamy/nie rozumiemy sekwencji ${ }^{56}$. W wyjątkowym reportażu skamandryty prowadzi to do myśli o zagubieniu, kłopotach z usensownieniem swojej pozycji we współczesnym świecie, odsłaniając egzystencjalne podłoże tekstu Iwaszkiewicza ${ }^{57}$. Natomiast w szkicu Andrzeja Stasiuka odczłowieczony pejzaż wiąże się z myślą o przemijaniu, o śmierci - zużywaniu miejsca i zużywaniu człowieka, któremu nowoczesność tylko pozornie może zaradzić.

Zaskakujące "spotkanie" utworów dwóch pisarzy, którzy w odmiennym czasie zaledwie "dotknęli" Śląska, nie wiążąc się z tym regionem w sposób trwalszy, odsłania jego melancholijny pejzaż - interesujący i - jak sądzę wciąż jeszcze literacko niewyeksploatowany.

\section{Melancholy Landscapes of Silesia}

\section{Summary}

The analysis juxtaposes Fotografie ze Ślaska by Jarosław Iwaszkiewicz with Andrzej Stasiuk's brief literary sketch I tak to się kiedyś wszystko skończy. By comparing such dissimilar texts, the author draws attention to the modes of representing industrial and postindustrial space when seen from a certain distance by writers who are unconnected to the region described. The comparative analysis reveals, however, not only differences but also surprising similarities. The texts interpreted share the conviction of a particular "photogenity" and melancholy of Silesian landscapes.

\footnotetext{
55 A. Stasiuk, Fado, s. 377-378.

56 M. Bieńczyk, Nie dla mnie sznur samochodów, w: tegoż, Książka twarzy, Warszawa 2012, s. 83.

57 Mocno eksponuje egzystencjalne podłoże twórczości J. Iwaszkiewicza T. Drewnowski, W stronę egzystencjalna, w: tegoż, Literatura polska 1944-1989. Próba scalenia. Obiegi - wzorce style, Kraków 2004, s. 218-219.
} 